\title{
Antifungal activity of some medicinal plant extracts against the most prevalent fungal pathogens causing spoilage of some fruits
}

\author{
Zakaria A. M. Baka ${ }^{1 *}$, Mamdouh S. Serag ${ }^{1}$, Amira I. Farag ${ }^{1}$ \\ ${ }^{1}$ Botany Department, Faculty of Science, Damietta University, New Damietta, 34517, Egypt.
}

Received: 24 May 2015 / Accepted: 7 September 2015

*Corresponding author: zakariabaka@yahoo.com

\begin{abstract}
Fungi are the major disease-causing agents of fruits. They cause considerable losses to post harvest fruits during transportation and storage. Ten infected fruit species were collected from the local markets in Damietta Governorate, Egypt for surveying the fungal pathogens on these fruits. Ten fungal species were isolated and identified, among them, Alternaria alternata and Fusarium oxysporum exhibited the most prevalent fungal species isolated from mandarins and grapes, respectively. In this study, the aqueous and ethanolic extracts of eleven wild medicinal plants were tested against the two prevalent fungi at five concentrations $(0,1,3,5,10 \%$; w/v). The greater relative inhibition of fungal growth, along with the lower C50 values revealed that the ethanolic extract of the tested plants exhibited the stronger antifungal activity when compared to water extracts. Out of the eleven plant species investigated, Thymus capitatus and Eucalyptus citriodora were the most effective for fungal growth, while Nicotiana glauca was the least effective. Therefore, we recommend the using of Thymus capitatus and Eucalyptus citriodora extracts as potential antifungal preservatives for fruits against fungal spoilage.
\end{abstract}

Keywords: Alternaria alternata, Antifungal activity, Fusarium oxysporum, Postharvest diseases, Plant extracts.

\section{Introduction}

Postharvest diseases are posing a major problem for the agricultural industry, especially in the developing countries. It has been estimated that between $10 \%$ and $40 \%$ losses of agricultural production worldwide arise from the postharvest loss (Enyiukwu et al. 2014). According to Arya (2010), of all losses caused by plant diseases, those that occur after harvest are the most costly.
Fruits are highly perishable products; their quality is affected by postharvest handling, transportation, storage and marketing (Wills et al., 1981; Liu and Ma, 1983). The improper handling, packaging, storage and transportation may result in decay and proliferation of microorganisms, which become activated because of the changing in physiological state of the fruits and vegetables (Wilson et al., 1991). Fruits, due to their low pH, high moisture content and rich nutrient composition are very susceptible to attack by pathogenic fungi; which 
in addition to causing rots may also produce mycotoxins; thereby making the fruits unfit for consumption (Phillip, 1984; Stinson et al., 1981; Moss, 2002). Several species of fungi and in some cases, bacteria participate in postharvest deterioration and rots of tubers and agroproduce. These include species of Aspergillus, Fusarium, Colletotrichum, Macrophomina, Penicillium and Rhizopus amongst several others (Enyiukwu et al., 2014).

At a time of increased public awareness about chemical treatments and development of fungicide resistance by postharvest pathogen populations, the adoption of alternative control means seems to be essential. However, an effective way to reduce losses of agroproduce requires the knowledge of epidemiology and complex interactions between host, pathogen, and control agents (Rouissi et al., 2013).

The most common method of protecting plants against the fungal attack is the use of synthetic fungicides, but their excessive use, complemented with high costs, the presence of residues in plants, and development of resistance, has imposed a negative effect on human health and the environment (Paster and Bulllerman, 1988).

In recent years, there has been a global trend toward the use of natural substances present in plants, fruits, vegetables, oilseeds, and herbs as antioxidants and functional foods (Kitts et al., 2000). Environment-friendly plant extract agents have been shown to be of great potential as an alternative to the synthetic fungicides (Zhang et al., 2005). The plant extracts have the advantages of being cheap, locally available, non-toxic and easily biodegradable. The antimicrobial properties of plant extracts have been reported with increasing frequency from different parts of the world (Cowan, 1999). The investigation of certain indigenous plants for their antimicrobial properties may yield useful results. Wild plants may contain a large source of effective secondary metabolites such as phenolics, alkaloids, tannins, saponins, glycosides and flavonoids, which may exert an antifungal activity (Hassan and Maswada, 2012; Maswada and Elzaawely, 2013)

The aim of the present study is to evaluate some wild medicinal plant extracts for controlling the predominant fungal pathogens causing postharvest diseases of some fruits collected Damietta Governorate markets.

\section{Materials and Methods}

\section{Collection of spoiled fruits}

Ten infected fruit species of economic importance growing in Egypt were collected from the local markets in Damietta Governorate (Table 1). Spoiled fruits with fungal infections were chosen and transferred to laboratory in sterile plastic polyethelene bags and isolation of fungal pathogens was done in the same day.

Table (1): Scientific and common names of fruits under study

\begin{tabular}{lll}
\hline \multicolumn{1}{c}{ Scientific name } & \multicolumn{1}{c}{ Common name } & \multicolumn{1}{c}{ Family } \\
\hline Malus domestica Borkh.cv. Barkher & Apple & Rosaceae \\
Musa sapientum L. cv. William & Banana & Musaceae \\
Vitis vinifera L. cv. Thompson & Grapes & Vitaceae \\
Pisidium guajava L. cv. Bassateen El Sabahia & Guajava & Myrtaceae \\
Citrus reticulata Blanco. cv. Balady & Mandarin & Rutaceae \\
Mangifera indica L. cv. Alfonso & Mango & Anacardiaceae \\
Citrus sinensis (L) Obseck cv. Balady & Orange & Rutaceae \\
Prunus domestica L. cv. Santa Rosa & Plum & Rosaceae \\
Punica granatum (L) cv. Manfalouty & Pomegranate & Punicaceae \\
Fragaria ananassa L.cv. Camarosa & Strawberry & Rosaceae \\
\hline
\end{tabular}

\section{Isolation and identification of fungal pathogens}

Fungal pathogens were isolated from fruits according the method of Chiejina (2008). Thin sections ( $2 \mathrm{~mm}$ diameter) were cut from the periphery of diseased fruits; surface sterilized in $0.1 \%$ mercuric chloride for $2-3 \mathrm{~min}$, and then rinsed 3 times with sterile distilled water. The sections were plated in water agar and the mycelium was transferred into clean Potato Dextrose Agar (PDA) plates containing penicillin $(100,000$ Units/L). The plates were incubated at $27 \pm 2^{\circ} \mathrm{C}$ for 6-7 days. Subcultures made aseptically from the plates into similar clean PDA plates and incubated under similar conditions until pure cultures were obtained. The identification of 
the isolated fungi was done macroscopically and microscopically. Macroscopic identification was based on culture growth patterns and mycelial color. Small portions of the fungal cultures were teased and mounted in lactophenol in cotton blue and examined microscopically. Fungal identification was confirmed with the aid of fungal identification manuals (Barnett and Hunter, 1999; Alexopoulos et al., 2002; Agrios, 2005; Ellis et $a l .$, 2007). The isolated fungi were maintained on PDA slants at $5^{\circ} \mathrm{C}$ for further use.

\section{Determination of percentage of fungal occurrence}

This was done to determine the frequency of occurrence of the different fungal isolates. Isolates taken from the spoiled fruits were cultured and the number of fungal isolates from each of the ten fruits were recorded and expressed as percentage of the total number of isolates, according to Ukeh and Chiejina (2012).

Percentage of occurrence $=\mathrm{X} \times 100 / \mathrm{N}$

$\mathrm{X}=$ number of isolates of each organism in each fruit.

$\mathrm{N}=$ Total number of isolates of all organisms in all fruits.

\section{Pathogenicity test}

Each of the fungal isolate obtained from the spoiled fruits were tested for their ability to cause the same disease condition previously observed in healthy fruits by the method of Franck et al. (2005). Healthy fruits were washed in sterile distilled water and surface sterilized by dipping into $0.1 \% \mathrm{HgCl}_{2}$ for 2 minutes and, with the aid of a sterile cork borer, cylindrical cores were removed from each fruit. Pure cultures of the isolated fungi were introduced into the open cores made within the fruits and the cores were sealed with sterile Vaseline. The fruits were kept at room temperature for 7-10 days. With the establishment of the disease, inocula were taken from the infected fruits and cultured. The organisms were re-isolated and identified as mentioned before. This was taken as evidence that the originally isolated organism from the spoiled fruit is the causative agent of the disease, thus confirming Koch's postulates (Nweke and Ibiam, 2012).

\section{Plant samples collection}

Eleven wild plant species were collected from natural habitats (Table 2). The plant species were identified according to Täckholm (1974); Boulos (1999-2005) and deposited as herbarium sheets at Botany Department, Faculty of Science, Damietta University.

Table (2): List of plant species used for preparation of plant extracts

\begin{tabular}{llll}
\hline \multicolumn{1}{c}{ Scientific name } & \multicolumn{1}{c}{ Common name } & \multicolumn{1}{c}{ Family } & \multicolumn{1}{c}{ Part Used } \\
\hline Moringa oleifera Lam. & Moringa & Moringaceae & Fruits \\
Ziziphus spina-christi $(\mathrm{L})$. & Sidr & Rhamnaceae & Leaves \\
Melia azedarach (L.) & Chinaberry tree & Meliaceae & Leaves \\
Nicotiana glauca Graham & Tobacco tree & Solannceae & Fruits \\
Cyperus rotundus $($ L.) & Purple nutsedge & Cyperaceae & Rhizomes \\
Schinus terebinthifolius Raddi & Brazilian pepper & Anacardiaceae & seeds \\
Lantana camara (L.) & Tickberry wild sage & Verbenaceae & Leaves \\
Zygophyllum aegyptium (L.) & Rotrate & Zygophyllaceae & Shoot \\
Delonix regia (Boj. ex Hook.) Raf & Royal poincina & Fabaceae & Bark \\
Eucalyptus citriodora LHér & Myrtle & Myrtaceaea & Shoot \\
Thymus capitatus (L.) Hoffmgg. et Link & Thyme & Lamiaceae & Shoot \\
\hline
\end{tabular}

\section{Preparation of plant powder}

The plant samples were washed with tap water 3 times and then rinsed in distilled water and dried under shade at laboratory temperature $\left(25-29^{\circ} \mathrm{C}\right)$ till they become crispy. Dried parts of the plants were ground using a blender and sieved to remove coarse particles.

\section{Preparation of plant extracts}

A known weight (1gm) of the used part of each plant was taken into $10 \mathrm{ml}$ solvent, either distilled water or $95 \%$ ethanol and extracted on a shaker (Lab Line Company) at $150 \mathrm{rpm}$ for 24 hours at $25^{\circ} \mathrm{C}$. The mixture was filtered through sterile Whatman filter paper No.1 and centrifuged (Xiangshui Fada Medical Apparatus Factory, Centrifuge model $800 \mathrm{D}$ ) twice at $4000 \mathrm{rpm}$ for 10 
minutes. In case of the aqueous extract, it was concentrated into half of the original volume and in case of the ethanolic extract, ethanol was completely evaporated and the dry residue was resuspended in half of the original volume and DMSO (dimethyl sulfoxide). The supernatant was poured in conical flasks and covered with cotton plugs and left for 10 minutes in a digital water bath (Kottermann model 3042 ) at $100^{\circ} \mathrm{C}$ to avoid contamination (Madavi and Singh, 2005). Different volumes $(0,1,3,5$ and $10 \mathrm{ml})$ were taken into $10 \mathrm{ml}$ double strength PDA media to give 0 , $1,3,5$ and $10 \%$ (w/v) extract respectively.

\section{Estimation of antifungal activity}

The agar-amended media was used according to Kumar et al. (2009) with some modifications. Aqueous and ethanolic plant extracts at the concentrations of $0,1,3,5$ and $10 \%$ were tested against the two predominant fungal species (Alternaria alternata and Fusarium oxysporum) isolated from mandarins and grapes, respectively. The solidified extract-amended media in the Petri dishes were inoculated, each alone at the center with $7 \mathrm{~mm}$ inoculum-disc of each tested fungus and incubated at $25 \pm 2^{\circ} \mathrm{C}$ for 7 days for Alternaria alternata and 4 days for Fusarium oxysporum. The diameter of fungal growth $(\mathrm{cm})$ was measured and the percentage inhibition of fungal growth was estimated relative to the control. The experiment was factorial with four main factors and three replicates (Petri dishes) in a completely randomized design. The four factors were: fungus species with 2 levels (Alternaria alternata and Fusarium oxysporum), plant species with eleven levels, extract with two levels (aqueous and ethanolic) and concentration of extract with five levels $(0,1,3,5$ and $10 \% \mathrm{w} / \mathrm{v})$. The relative potency of plant extracts was estimated in terms of the concentration leading to $50 \%$ inhibition of fungal growth $\left(\mathrm{C}_{50}\right)$.

\section{Statistical analysis}

The relative inhibition of fungal growth estimated as a percentage of the control was arcsine transformed before performing statistical analysis to ensure homogeneity of variance. Data were analyzed using SPSS version 22 and the effect of the main factors (fungus, plant species, extract and concentration of the extract) and their interaction were assessed using four ways ANOVA. Main separation was performed using the Duncan's multiple range tests at $\mathrm{p} \square 0.05$.

\section{Results}

Ten fungal pathogens were isolated from ten spoiled fruit species; viz: Alternaria alternata, Aspergillus niger, A. nidulans, A. flavus, A. ochraceous, Cladosporium herbarum, Fusarium oxysporum, Penicillium chrysogenum, P. expansum, and Rhizopus stolonifer. The most prevalent fungal species were Alternaria alternata and Fusarium oxysporum with the relative occurrence of $25 \%$ and $18 \%$, respectively, of the total number of isolates (Table 3). Mandarins and grapes exhibited $100 \%$ successful infection by these two pathogens after the pathogenicity test (Fig. 1).

These two fungal species were subjected to biological control in vitro by using aqueous and ethanolic extracts of eleven plant species at five concentrations $(0-10 \%)$. Table 4 shows highly significant effect of plant species and type of extract on fungal growth as well as a highly significant difference in fungal susceptibility to treatments.

Tables 5 and 6 shows that $F$. oxysporum was more affected by the water and ethanolic extracts of all plants than A. alternata, but ethanolic extract exhibited a more potent inhibitory effect on the growth of the two fungal species than that of aqueous extract. Out of the 11 plant species investigated, Thymus capitatus was the most potent with an average inhibition (for both aqueous and ethanolic extracts) of $41 \%$ and $53 \%$, respectively. In addition, Eucalyptus citriodora came the second with an average inhibition of $28.4 \%$ and $42 \%$, respectively when compared with the control. On the other hand, Nicotiana glauca exhibited the least effective plant with an average inhibition of $6 \%$ and $4.8 \%$, respectively. The remaining eight plant species exhibited moderate inhibition with different magnitude and rank, depending on the type of extract and fungal species.

Increasing the concentration of the plant extract led to a progressive inhibition of fungal growth; yet the concentration-response relationship differed in the two fungal species according to plant species and type of extract. For example, a saturable trend, with variable magnitude depending on the fungus, plant species and the extract was exhibited in terms of both extracts of Moringa oleifera, Ziziphus spinachristi and Delonix regia on both fungal species and of Melia azedarach on A. alternata, and ethanolic extract only of Thymus capitatus, Lantana camara, Cyperus rotundus, Schinus 
terebinthifolius, Zygophyllum aegyptium and Eucalyptus citroidora on both fungal species, and aqueous extract only of Thymus capitatus, Schinus terebinthifolius, Zygophylleum aegyptium and Eucalyptus citriodora on F. oxysporum (Figs. 2 and 3). This saturable trend was more frequent in case of ethanolic extract than aqueous extract in case of $F$. oxysporum than A. alternata. By contrast, a linear trend was appeared in case of both extracts of Nicotiana glauca and by the aqueous extracts only of Cyperus rotundus and Lantana camara on both fungal species and by the aqueous extracts of Schinus terebinthifolius, Zygophyllum aegyptium, Thymus capitatus and Eucalyptus citriodora on A. alternata and of Melia azedarach on $F$. oxysporum and by only the ethanolic extracts of Melia azedarach on $F$. oxysporum.

Table (3): The isolated fungal species from spoiling fruits. Each value is the mean of 5 replicates \pm SE

\begin{tabular}{|c|c|c|c|c|}
\hline Fruit & Disease & Isolated fungus & $\begin{array}{l}\text { No. of } \\
\text { colonies }\end{array}$ & $\begin{array}{l}\text { Relative } \\
\text { occurrence } \\
\text { (\% of total) }\end{array}$ \\
\hline \multirow{3}{*}{ Apple } & Alternaria rot & Alternaria alternata (Fr.) Keissl & 13 & 4.48 \\
\hline & Blue mold rot & Penicillium expansum Link & 10 & 3.44 \\
\hline & Black mold rot & Aspergillus niger van Tieghem & 9 & 3.1 \\
\hline \multirow[t]{3}{*}{ Banana } & Alternaria rot & Alternaria alternata (Fr.) Keissl & 15 & 5.17 \\
\hline & Rhizopus rot & Rhizopus stolonifer (Ehrenb. Fr.) Vuill & 9 & 3.1 \\
\hline & Black mold rot & Aspergillus niger van Tieghem & 4 & 1.37 \\
\hline \multirow[t]{2}{*}{ Grapes } & Dry rot & Fusarium oxysporum Sch. Em. Syn. Hansen & 20 & 6.89 \\
\hline & Rhizopus rot & Rhizopus stolonifer (Ehrenb. Fr.) Vuill & 6 & 2.06 \\
\hline \multirow[t]{3}{*}{ Guajava } & Black mold rot & Aspergillus ochraceus Wilhelm & 10 & 3.45 \\
\hline & Black mold rot & Aspergillus niger van Tieghem & 6 & 2.06 \\
\hline & Alternaria rot & Alternaria alternata (Fr.) Keissl & 20 & 6.89 \\
\hline \multirow[t]{2}{*}{ Mandarin } & Black mold rot & Aspergillus nidulans G. Winter & 12 & 4.14 \\
\hline & Black mold rot & Aspergillus ochraceus Wilhelm & 13 & 4.48 \\
\hline \multirow[t]{3}{*}{ Mango } & Black mold rot & Aspergillus niger van Tieghem & 3 & 1.03 \\
\hline & Black mold rot & Aspergillus flavus Link & 5 & 1.72 \\
\hline & Sooty spot & Cladosporium herbarium (Pers.) Link & 16 & 5.52 \\
\hline \multirow[t]{3}{*}{ Orange } & Black mold rot & Aspergillus niger van Tieghem & 10 & 3.45 \\
\hline & Blue mold rot & Penicillium chrysogenum Thom & 9 & 3.1 \\
\hline & Black mold rot & Aspergillus flavus Link & 7 & 2.41 \\
\hline \multirow[t]{3}{*}{ Plums } & Alternaria rot & Alternaria alternata $(\mathrm{Fr}$.$) Keissl$ & 25 & 8.62 \\
\hline & Dry rot & Fusarium oxysporum Sch. Em. Syn. Hansen & 20 & 6.89 \\
\hline & Rhizopus rot & Rhizopus stolonifer (Ehrenb. Fr.) Vuill & 5 & 1.72 \\
\hline Pomegranate & Blue mold rot & Penicillium expansum Link & 20 & 6.89 \\
\hline \multirow{2}{*}{ Strawberry } & Rhizopus rot & Rhizopus stolonifer (Ehrenb. Fr.) Vuill & 10 & 3.45 \\
\hline & Dry rot & Fusarium oxysporum Sch. Em. Syn. Hansen & 13 & 4.45 \\
\hline $\begin{array}{l}\text { Total number of } \\
\text { colonies }\end{array}$ & & & 290 & \\
\hline
\end{tabular}

Table (4): Four-way ANOVA of the effect of the main factors (plant species, type of extract and concentration of the extract) and their interactions on the percentage inhibition of Alternaria alternata and Fusarium oxysporum.

\begin{tabular}{llll}
\hline \multicolumn{1}{c}{ Source of variation } & df & F & Sig. \\
\hline Fungus & 1 & 1055.266 & .000 \\
Plant species & 10 & 893.187 & .000 \\
Extract & 1 & 2101.675 & .000 \\
Conc. & 4 & 4044.657 & .000 \\
Fungus * Plant species & 10 & 163.753 & .000 \\
Fungus * Extract & 1 & 38.524 & .000 \\
Fungus * Conc. & 4 & 77.348 & .000 \\
Plant species * Extract & 10 & 70.280 & .000 \\
Plant species * Conc. & 40 & 114.209 & .000 \\
Extract * Conc. & 4 & 158.929 & .000 \\
Fungus * Plant species * Extract & 10 & 33.380 & .000 \\
Fungus * Plant species * Conc. & 40 & 17.574 & .000 \\
Fungus * Extract * Conc. & 4 & 6.930 & .000 \\
Plant species * Extract * Conc. & 40 & 15.317 & .000
\end{tabular}


Fungus * Plant species * Extract * Conc.

40

8.586

.000

Table (5): Effect of plant species and type of extract on the growth of A. alternata. Each value is the mean of 5 replicates \pm SE. Means with common letters are not significantly different at $\mathrm{p}<0.05$.

\begin{tabular}{llc}
\hline \multirow{2}{*}{ Plant species } & \multicolumn{2}{l}{ Inhibition of fungal growth $(\%$ of control) } \\
\cline { 2 - 3 } & Aqueous extract & Ethanolic extract \\
\hline Nicotina glauca & $5.23 \pm 1.31^{\mathrm{a}}$ & $6.89 \pm 1.76^{\mathrm{a}}$ \\
Schinus terebinthifolius & $6.18 \pm 1.44^{\mathrm{ab}}$ & $12.4 \pm 2.25^{\mathrm{bcd}}$ \\
Lantana camara & $6.23 \pm 2.22^{\mathrm{abc}}$ & $20.4 \pm 3.78^{\mathrm{e}}$ \\
Delonix regia & $6.27 \pm 1.21^{\mathrm{abcd}}$ & $10.7 \pm 1.85^{\mathrm{b}}$ \\
Ziziphus spina-christi & $10.8 \pm 1.85^{\mathrm{e}}$ & $11.8 \pm 2.13^{\mathrm{bc}}$ \\
Melia azedarach & $12.1 \pm 3.64^{\mathrm{ef}}$ & $34.5 \pm 6.03^{\mathrm{i}}$ \\
Eucalyptus citriodora & $15.0 \pm 3.86^{\mathrm{g}}$ & $41.8 \pm 8.32^{\mathrm{j}}$ \\
Zygophyllum aegyptium & $18.2 \pm 4.26^{\mathrm{h}}$ & $28.6 \pm 5.04^{\mathrm{gh}}$ \\
Cyperus rotundus & $19.1 \pm 3.65^{\mathrm{hi}}$ & $22.6 \pm 4.45^{\mathrm{f}}$ \\
Moringa oleifera & $27.0 \pm 4.37^{\mathrm{j}}$ & $27.5 \pm 4.58^{\mathrm{g}}$ \\
Thymus capitatus & $35.6 \pm 8.15^{\mathrm{k}}$ & $46.8 \pm 9.37^{\mathrm{k}}$ \\
\hline Total of all species & $14.7 \pm 1.33^{\mathrm{a}}$ & $24.0 \pm 1.79^{\mathrm{c}}$ \\
\hline Total of A. alternata & $19.34 \pm 1.14^{\mathrm{a}}$ & \\
\hline
\end{tabular}

Table (6): Effect of plant species and type of extract on the growth of $F$. oxysporum. Each value is the mean of 5 replicates \pm SE. Means with common letters are not significantly different at $\mathrm{p}<0.05$.

\begin{tabular}{llc}
\hline \multirow{2}{*}{ Plant species } & \multicolumn{2}{l}{ Inhibition of fungal growth $(\%$ of control) } \\
\cline { 2 - 3 } & Aqueous extract & Ethanolic extract \\
\hline Nicotiana glauca & $0.38 \pm 0.66^{\mathrm{a}}$ & $9.24 \pm 2.14^{\mathrm{a}}$ \\
Melia azedarach & $7.46 \pm 1.67^{\mathrm{b}}$ & $20.2 \pm 5.08^{\mathrm{c}}$ \\
Schinus terebinthifolius & $11.2 \pm 3.46^{\mathrm{c}}$ & $31.7 \pm 4.43^{\mathrm{g}}$ \\
Delonix regia & $11.7 \pm 2.18^{\mathrm{cd}}$ & $17.7 \pm 2.89^{\mathrm{b}}$ \\
Ziziphus spina-christi & $16.9 \pm 2.39^{\mathrm{e}}$ & $28.4 \pm 3.92^{\mathrm{def}}$ \\
Cyperus rotundus & $18.1 \pm 3.85^{\mathrm{ef}}$ & $27.8 \pm 4.75^{\mathrm{de}}$ \\
Zygophyllum aegyptium & $20.2 \pm 2.83^{\mathrm{g}}$ & $46.6 \pm 7.11^{\mathrm{hi}}$ \\
Moringa oleifera & $25.1 \pm 4.07^{\mathrm{h}}$ & $27.4 \pm 4.37^{\mathrm{d}}$ \\
Eucalyptus citriodora & $33.4 \pm 5.27^{\mathrm{i}}$ & $50.6 \pm 7.40^{\mathrm{j}}$ \\
Lantana camara & $37.7 \pm 5.53^{\mathrm{j}}$ & $45.0 \pm 6.61^{\mathrm{h}}$ \\
Thymus capitatus & $47.1 \pm 9.92^{\mathrm{k}}$ & $59.0 \pm 9.53^{\mathrm{k}}$ \\
\hline Total of all species & $20.9 \pm 1.67^{\mathrm{b}}$ & $33.0 \pm 2.02^{\mathrm{d}}$ \\
\hline Total of $F$. oxysporum & $26.95 \pm 1.35^{\mathrm{b}}$ & \\
\hline
\end{tabular}
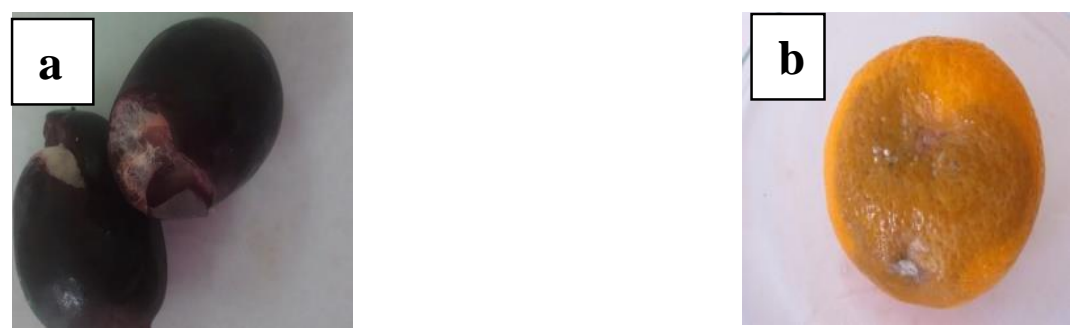

Fig. 1. Pathogenicity tests on healthy fruits showing the appearance of fungal infection on (a) Grapes with Fusarium oxysporum and (b) Mandarin with Alternaria alternata.

Although the ethanolic extract of the studied plant species exerted, in general, a stronger inhibitory effect on fungal growth than the aqueous extract, the concentration at which the maximum difference between the two extracts exists differed in the two fungal species and depending on the plant species. This difference was progressive with the increasing of extract concentration in the following cases: the effect of Melia azedarach, Schinus terebinthifolius, Eucalyptus citriodora and Delonix regia on both fungi, and of Ziziphus spina-christi, Nicotiana glauca and Zygophyllum aegyptium on $F$. oxysporum. Another pattern of maximum difference in the moderate concentrations of the extract was pronounced by Cyperus rotundus, Lantana camara and Thymus 
capitatus on both fungi and of Nicotiana glauca and Zygophyllum aegyptium on A. alternata. A third case of negligible difference between the two extracts encountered in the case of Moringa oleifera on both fungi and of Ziziphus spinachristi on A. alternata.

Table 7 shows the relative potency of the aqueous and ethanolic extracts of the studied plant species on fungal growth in terms of $\mathrm{C}_{50}$; calculated from the concentration-response relationships of Figures 2 and 3 . In general, the value of $\mathrm{C}_{50}$ of the ethanolic extract of the different species was much lower than that of the aqueous extract. In the majority of the studied species, the magnitude of inhibition of fungal growth by the aqueous extract was too low to allow the calculation of the $\mathrm{C}_{50}$. It was only possible to estimate $\mathrm{C}_{50}$ of the aqueous extract for the most potent species (Thymus capitatus) on the two fungal species $(4.7 \%$ and $3 \%$ for A. alternata and $F$. oxysporum, respectively) and for Eucalyptus citriodora and Schinus terebinthifolius (6.9\% and 6\% respectively) on $F$. oxysporum.

Table (7): The concentration of plant extracts leading to $50 \%$ inhibition of fungal growth $\left(\mathrm{C}_{50}\right)$

\begin{tabular}{|c|c|c|c|c|}
\hline \multirow[b]{2}{*}{ Plant species } & \multicolumn{2}{|c|}{$\begin{array}{l}\mathrm{C}_{50}(\%) \\
\text { Alternaria alternata }\end{array}$} & \multicolumn{2}{|c|}{$\begin{array}{l}\mathrm{C}_{50}(\%) \\
\text { Fusarium oxysporum ooxysporum }\end{array}$} \\
\hline & Aqueous & Ethanolic & Aqueous & Ethanolic \\
\hline Nicotiana glauca & - & - & - & - \\
\hline Schinus terebinthifolius & - & - & 6 & 3 \\
\hline Lantana camara & - & - & - & - \\
\hline Delonix regia & - & - & - & - \\
\hline Zizyphus spina- christi & - & - & - & - \\
\hline Melia azedarach & - & 6.2 & - & 9.8 \\
\hline Eucalyptus citriodora & - & 3.7 & 6.9 & 1.7 \\
\hline Zygophyllum aegyptium & - & 8.3 & - & 2.5 \\
\hline Cyperus rotundus & - & - & - & 10 \\
\hline Moringa oleifera & - & 10 & - & - \\
\hline Thymus capitatus & 4.7 & 2.7 & 3 & 1.6 \\
\hline
\end{tabular}
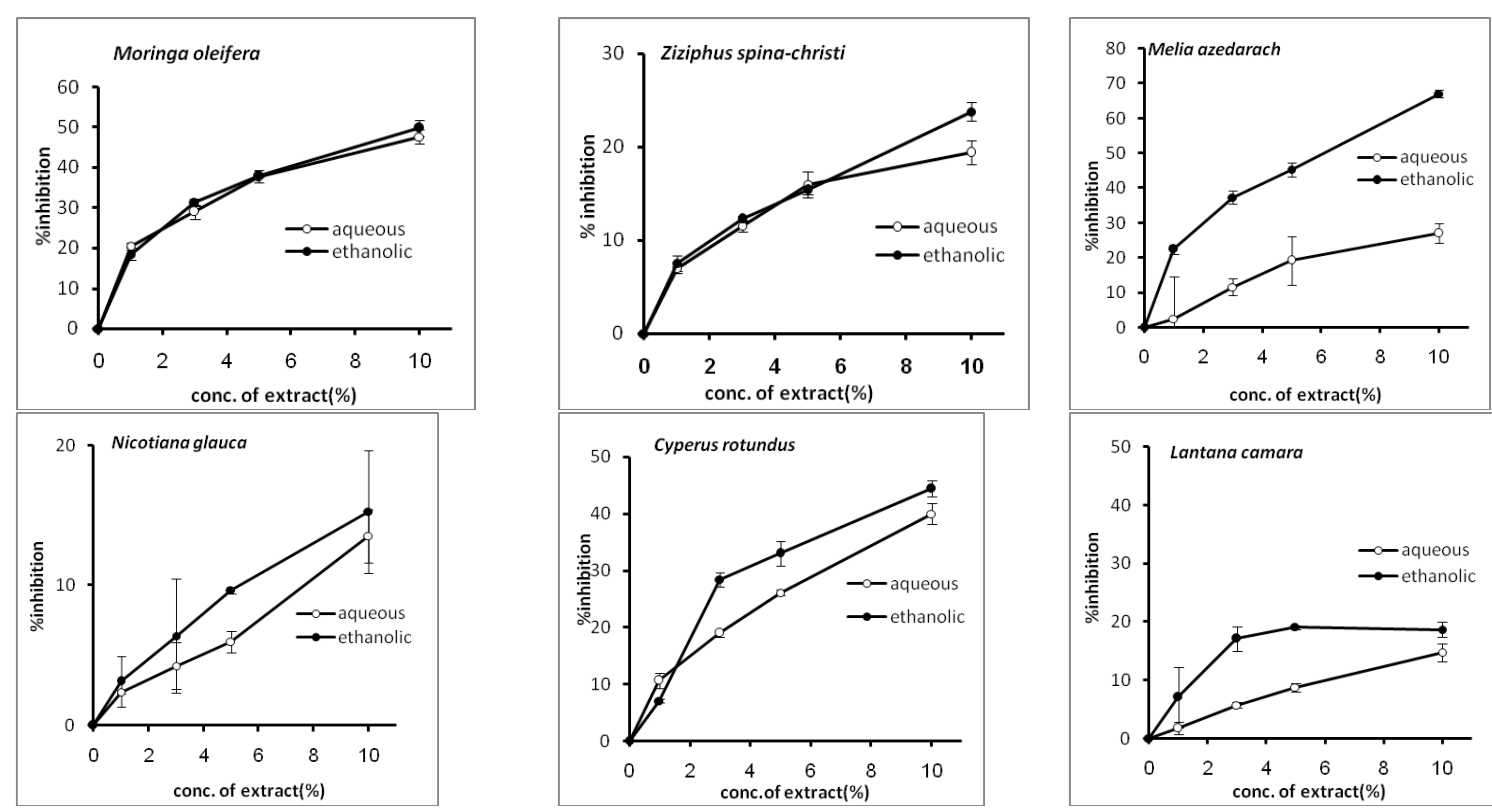

Fig. 2. Effect of aqueous and ethanolic plant extracts of Moringa oleifera, Ziziphus spina-christi, Melia azedarach, Nicotiana glauca, Cyperus rotundus and Lantana camara on growth of A. alternata. Each value is the mean of three replicates \pm S.E. 

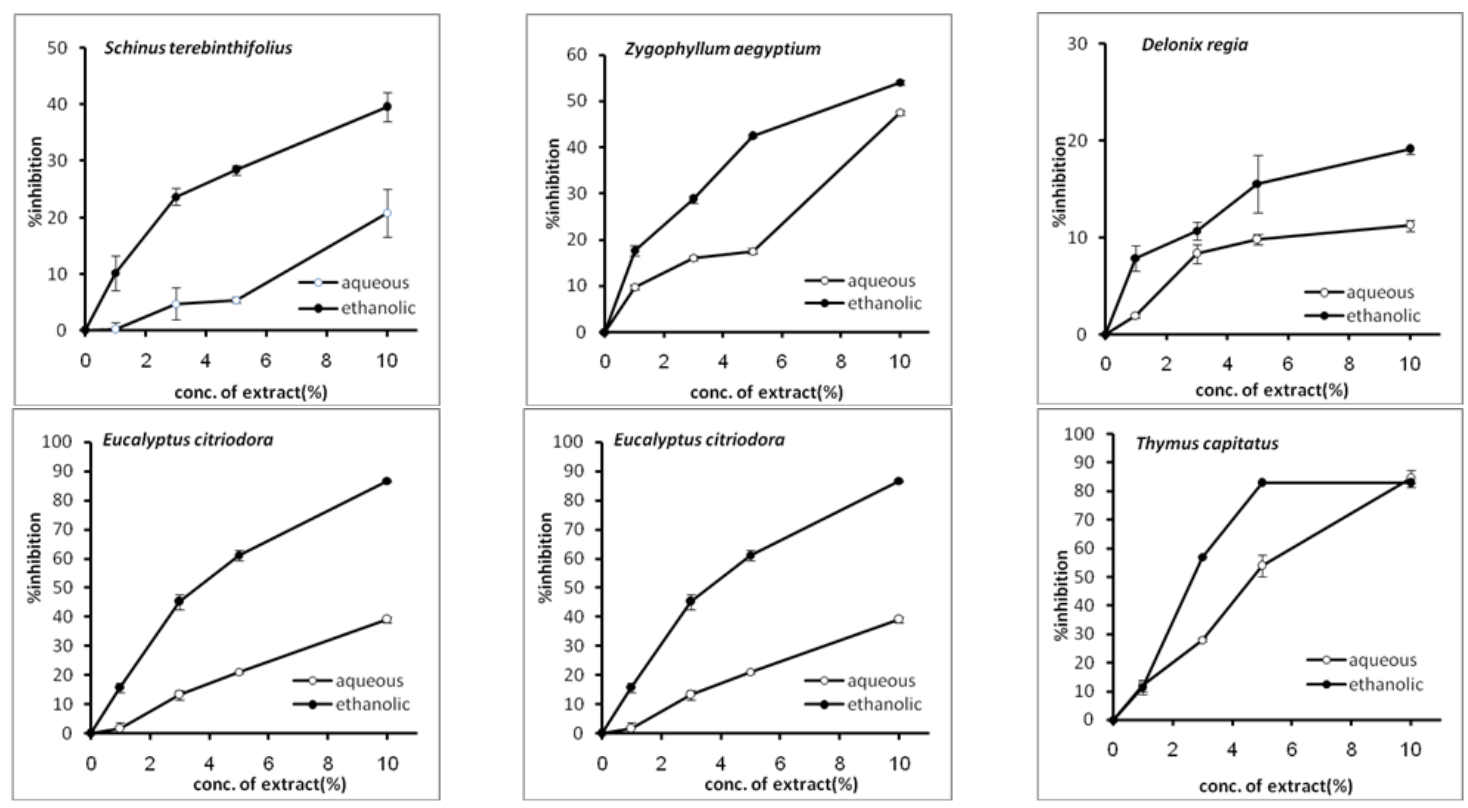

Fig. 2 cont. Effect of aqueous and ethanolic extracts of Schinus terebinthifolius, Zygophyllum aegyptium, Delonix regia, Eucalyptus citriodora and Thymus capitatus on growth of A. alternata. Each value is the mean of three replicates \pm S.E.
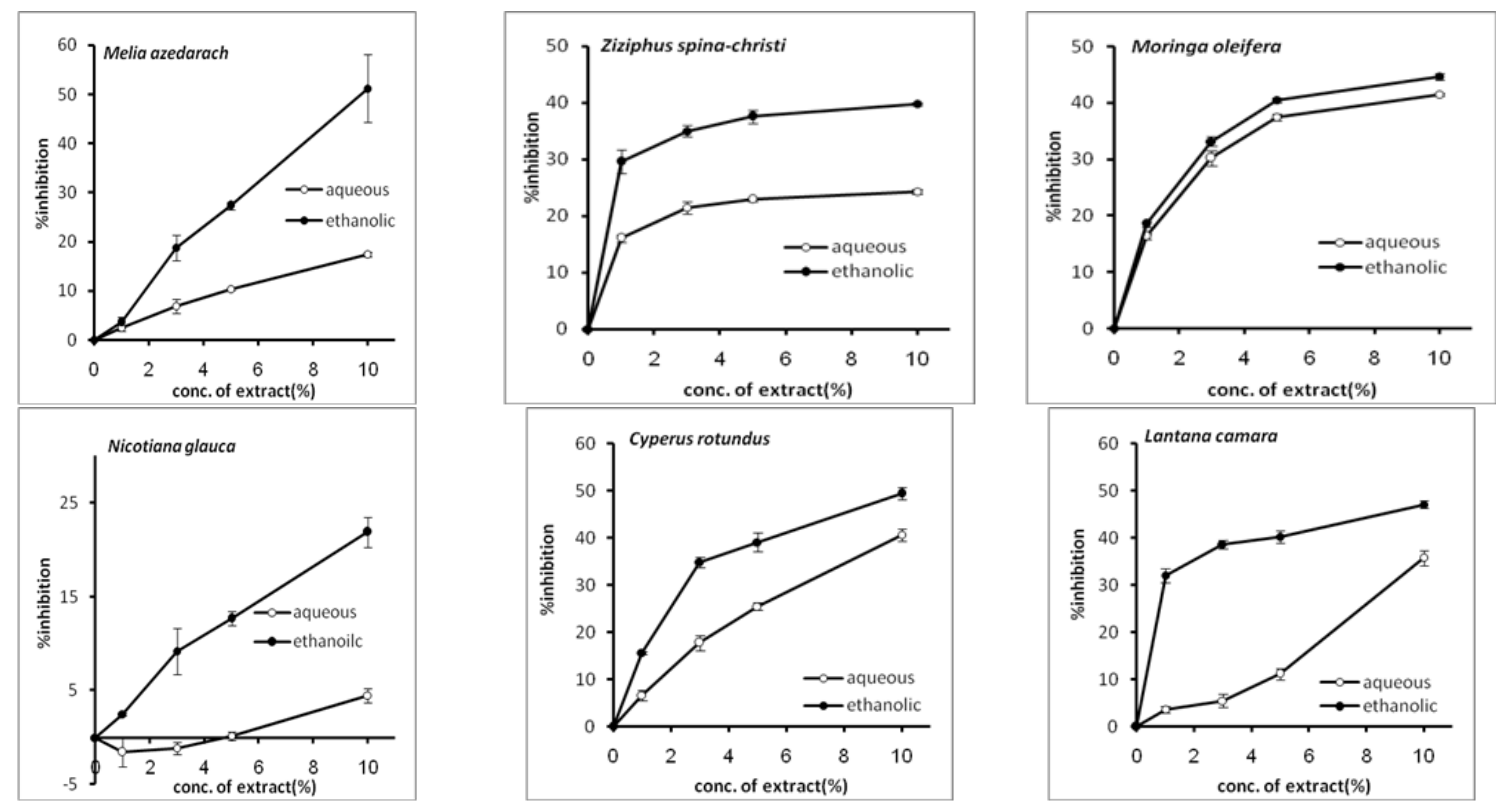

Fig. 3. Effect of aqueous and ethanolic extracts of Moringa oleifera, Ziziphus spina-christi, Melia azedarach, Nicotiana glauca, Cyperus rotundus and Lantana camara on growth of $F$. oxysporum. Each value is the mean of three replicates \pm S.E.
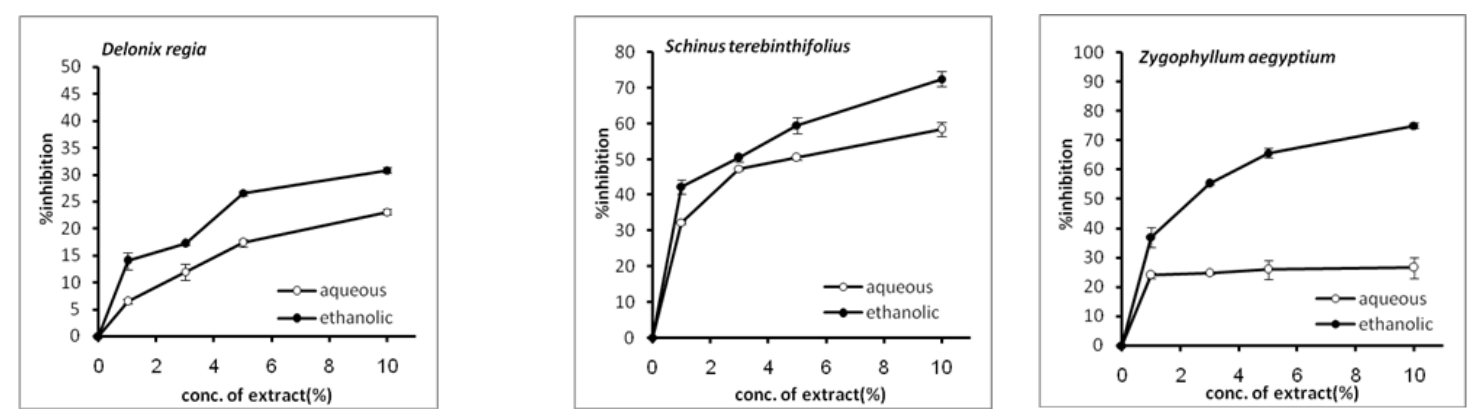

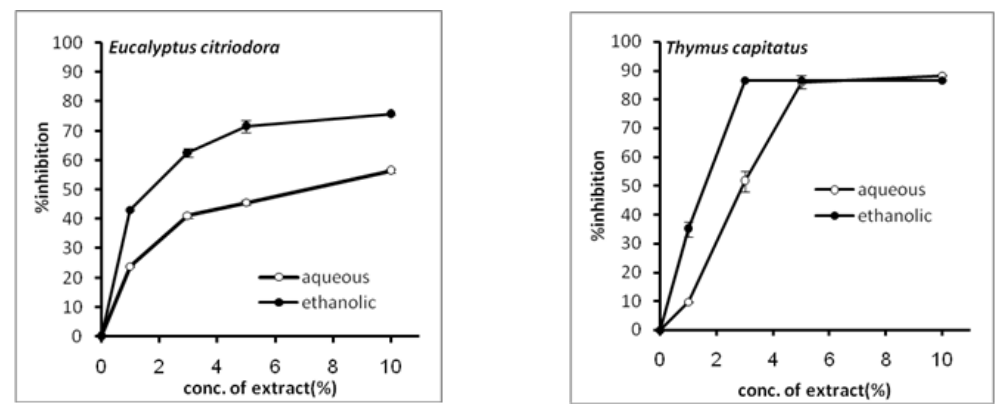

Fig. 3 cont. Effect of aqueous and ethanolic extracts of Schinus terebinthifolius, Zygophyllum aegyptium, Delonix regia, Eucalyptus citriodora and Thymus capitatus on growth of $F$. oxysporum. Each value is the mean of three replicates \pm S.E.

\section{Discussion}

Postharvest loss of fruits as a result of fungal infection is a severe problem facing the world particularly in the developing countries. The traditional measure to limit this problem is the use of chemical fungicides. But, because of their dangerous consequences for human health, biological control of spoiled fruits by medicinal plant extracts is the update trend to solve this problem.

The eleven plant species investigated in the present study exhibited diverse antifungal activities which varied according to the fungal species, plant species and type of extract. In general, Thymus capitatus and Eucalyptus citriodora exhibited the strongest effect, whereas Nicotiana glauca was the least effective; and the ethanolic extract was more potent than the aqueous extract in the majority of species. This is may be due to the variation in quantity of the active constituents of different plant species, and also to the efficiency of the solvent to extract these substances. In this study, ethanol had a greater capability for the extraction of active substances from testing plants than water did which in agreement of the results obtained by Stephan $e t$ al. (2005).

The antifungal activity of plant extracts may be related to the presence of many bioactive compounds such as flavonoids, terpenoids, alkaloids, tannins, steroids, glycosides, phenolics (Leicach et al. 2010; Yaber Grass and Leicach 2011). These secondary metabolites, also known as allelochemicals, are normally produced by the medicinal plants to provide protection against stress conditions, invasion of pathogens and is also involved in the plant-plant interaction; thus allowing the successful survival of the plant against other species and the invading microorganisms (Matsuki et al., 2011).
The outstanding antifungal activity of Thymus capitatus and Eucalyptus citroidora can be related to the unique secondary metabolites produced by the two species. In this respect, Lee et al. (2007) reported that the occurrence of several active antifungal compounds, including citronellal and isopulegol in Eycalyptus citriodora essential oil and $\rho$-cymene, $\boldsymbol{\gamma}$-terpinene and thymol in Thymus capitatus. These active substances, because of their considerable lipophilicity, are subjected to extraction by ethanol to a greater extent than by water, which can partially explain the stronger antifungal efficiency of the ethanolic extract.

In agreement with this postulation, Sani et al. (2014) and Shagel et al. (2012) reported that the ethanolic and aqueous extracts of Eucalyptus spp. share some components, but differ in others. Both the ethanolic and aqueous extracts contain large amounts of saponins, while the aqueous extract contains tannins, saponins, glycosides, steroids and anthraquinones but no alkaloids, flavonoids and terpenoids; and the ethanolic extract contain tannins and steroids but no glycosides and anthraquinone. The presence of these phytochemicals in Eucalyptus spp. justifies manipulation of the plant in the management and curing of various ailments. Likewise, it has been reported that Thymus capitatus has a powerful antifungal activity by virtue of its high content of a wide range of bioactive compounds like essential oils which can act as biogenetic precursors of phenolic compounds such as $\rho$ cimene, $\gamma$-terpinene, and $\beta$-cariophyllene; in addition to its high content of phenols such as carvacrol (Mariateresa et al., 2013). The mechanism of action of carvacrol and thymol as fungicides appears to be through the inhibition of ergosterol biosynthesis and disruption of membrane integrity of the fungus as reported by Bouchra et al. (2003) and Ahmed et al. (2011). In addition, preliminary phytochemical screening of Thymus capitatus revealed the presence of saponins, resins, flavonoids, essential and fixed 
oils; compounds of profound inhibitory effect against several bacteria and fungi (Kandil et al., 1994). In addition, Tabti et al. (2015) identified fifteen fatty acids accounting for $95 \%$ of the lipid content responsible for the in vitro antifungal activity of this species.

The potency of the antifungal activity of plant extracts was estimated in terms of the relative inhibition of fungal growth below the control. Nevertheless, this efficiency can be estimated also in terms of the $\mathrm{C}_{50}$. The two measures lead to the same conclusion that the ethanolic extract is more powerful than the aqueous extract and that the most potent species are Thymus capitatus and Eucalyptus citriodora. From the data of Table 7, it is clear that the values of $\mathrm{C}_{50}$ of the ethanolic extracts are more frequent and of lower magnitude than those of the aqueous extracts and that Thymus capitatus and Eucalyptus citriodora yielded the lowest $\mathrm{C}_{50}$ among the studied species. Normally, the lower the $\mathrm{C}_{50}$ the more potent is the antifungal activity of the extract; and whenever an extract has no value for $\mathrm{C}_{50}$ this means that the antifungal activity of this extract is too weak to the extent that the relative inhibition of fungal growth never attained $50 \%$ even at the top concentration used $(10 \% \mathrm{w} / \mathrm{v})$.

The two fungal species examined exhibited different susceptibility towards the action of plant extract; and in general $F$. oxysporum was more affected than $A$. alternata. The differential susceptibility of fungal species to active plant ingredients is well documented and Lee et al. (2007) reported that out of the five fungal species examined, $F$. oxysporum proved to be the most susceptible fungus to the action of the essential oils of five plant species including Eucalyptus citriodora and Thymus spp.

The difference in the concentration-response relationship between the different plant species and according to the fungal species and type of extract demonstrated in Figures 2 and 3 suggests different modes of action of the different plant extracts on the two fungal species. The saturable relationship always refers to a stronger effect of the extract which approaches an asymptote at a lower dose, thus yielding a lower $\mathrm{C}_{50}$ compared to the extract exhibiting the linear trend. In support to this postulation, the saturable trend was more frequent, and more evident in the ethanolic extracts of the majority of the studied plant species than in the aqueous extracts, and the reverse was true for the linear trend. In this respect, AbdelMogib et al. (2001) found that the ethanolic extract of Tamarix aphylla was inhibitory to the growth of a diverse array of microorganisms of bacteria and fungi including Fusarium spp. than the aqueous extract.

\section{Conclusion}

In conclusion, we recommend using Thymus capitatus and Eucalyptus citriodora extracts as preservatives for fruits against fungal attack.

\section{Acknowledgement}

The authors would like to thank Dr. Taha ElKatony, for his kind help concerning the statistical analysis of the data..

\section{References}

Abdel-Mogib M, Basaif S, Al-Garni SM (2001) Antimicrobial activity and chemical constituents of leaf extracts of Tamarix aphylla. Alex. J. Pharm. Sci. 15:121-124.

Ahmed A, Khan A, Akhtar F, Yousuf S, Xess I, Khan LA, Manzzoor N (2011) Fungicidal activity of thymol and carvacrol by disrupting ergosterol biosynthesis and membrane integrity against Candida. Eur. J. Clin. Microbiol. Infect. Dis. 30: 4150.

Agrios GN (2005) Plant pathology, (5th ed). Academic press, New York, pp. 922.

Alexopoulos CO, Mims CW, Blackwell M (2002) Introductory mycology (4th ed). John Wiley and Sons, Inc. Singapore, pp 869.

Arya A (2010) Recent advances in the management of plant pathogens: Botanicals in the fungal pest management. In: Arya A, Perello AE (eds) Management of fungal plant pathogens. CAB International UK, p.1-25.

Barnett HL, Hunter BB (1999) Illustrated genera of imperfect fungi (4th ed.). The American Phytopathological Society. St. Paul, Minnessota, USA, pp. 218.

Bouchra C, Achouri M, Idrissi Bassani L M and Hmamouchi M (2003) Chemical composition and antifungal activity of essential oils of seven Moroccan Labiatae against Botrytis cinerea Pers: Fr. J. Ethnopharmacol. 89:165-169.

Boulos L (1999-2005) Flora of Egypt.. AlHadara Publishing, Cairo, Egypt (Vol.1-4).

Chiejina NV (2008) Mycoflora of some salad vegetables. Bio-Research.6:392-395.

Cowan MM (1999) Plant products as antimicrobial agents. Clin. Microbiol. Rev. 10: 564-582. 
Ellis D, Davis S, Alexiou H, Handke R, Bartley R (2007) Descriptions of medical fungi (2nd ed). Mycology Unit Womens Hospital North Adelaide, Australia, pp 198.

Enyiukwu DN, Awurum AN, Nwaneri JA (2014) Efficacy of plant-derived pesticides in the control of myco-induced postharvest rots of tubers and agricultural products: A review. Net. J. Agr. Sc. 2: $30-46$.

Franck J, Latorre BA, Torres R, Zoffoli JP (2005) The effect of preharvest fungicide and postharvest sulfur dioxide use on postharvest decay of table grapes caused by Penicillium expansum. Postharv. Biol. Technol. 37: 20-30.

Hassan NS, Maswada HF (2012) Proximate and phytochemical analyses of Asparagus stipularis and Cyperus capitatus and their antioxidant activities. Proceedings of the 11th Conference of the Agricultural Development Researches, March 27-30, 2012, Ain Shams University, Egypt.

Kandil O, Radwan NM, Hassan AB, Amer AMM, El Banna HA, Amer WMM (1994) Extracts and fractions of Thymus capitatus exhibit antimicrobial activities. J. Ethnopharmacol. 44: 19-24.

Kitts DD, Wijewickreme AN, Hu C (2000) Antioxidant properties of a North American ginseng extract. Mol. Cell. Biochem. 203:1-10.

Kumar N, Singh RK, Adaj MN, Singh RB (2009) Effect of aqueous leaf and bark extracts of Mimusops elengi (L.) on radial growth and sclerotial formation of Sclerotinia sclerotiorum (Lib.) De Bary, a polyphagous fungus. Protect. Agric. Technol. 5: 288-300.

Lee SO, Choi GJ, Jang KS, Lim HK, Chok Y, Kim JC (2007) Antifungal activity of five plant essential oils as a fumigant against postharvest and soil borne plant pathogenic fungi. Plant Pathology. J. 23:97102.

Leicach SR, Garau AM, Guarnaschelli AB, Yaber Grass MA, Sztarker ND, Dato A (2010) Changes in Eucalyptus camaldulensis essential oil composition as response to drought preconditioning. J. Plant Interact. 5: 205-210.

Liu MS, Ma PC (1983) Post-harvest problems of vegetables and fruits in the tropics and subtropics. Asian Vegetable Research and Development Center. 10th Anniversary Monograph Series. Taiwan, China.14.

Madavi S and Singh RP (2005) Management of. Mushroom pathogens through botanicals. Ind. Phyto. Pathol. 58: 189-193.

Mariateresa R, Suraci F, Postorino S, Serra D, Roccotelli A, Agosteo GE (2013) Essential oil chemical composition and antifungal effects on Sclerotium cepivorum of Thymus capitatus wild populations from Calabria, Southern Italy. Braz. J. Pharmaco. 23: 239-248.
Maswada HF, Elzaawely AA (2013) Nutritive value of Stipagrostis lanata (Forssk.) De Winter as a feed for livestock. Asian J. Crop Sci. 5: 216-221.

Matsuki M, Foley WJ, Floyd RB (2011) Role of volatile and non-volatile plant secondary metabolites in host tree selection by Christmas beetles. J. Chemical Ecol. 37: 286-300.

Moss MO (2002) Mycotoxin review. 1. Aspergillus penillium. Mycologist 16:116-119.

Nweke CN, Ibiam OFA (2012) Pre and post harvest fungi associated with the soft rot of the fruit of Annona muricata, and their effects on the nutrient content of the pulp. Amer. J. Food Nutr. 2: 78-85.

Paster N, Bullerman LB (1988) Mould spoilage and mycotoxin formation in grains as collected by physical means. Int. J. Food Microbial. 7: 257-265.

Phillip DJ (1984) Mycotoxins as a post-harvest problem. In: Moline HE (ed.) Post-harvest pathology of fruits and vegetables; Postharvest losses in perishable crops. Agricultural experimental Station. University of California, Berkeley Publications, NE. pp. 50-54.

Rouissi W, Sanzani S, Ligorio A, Youssef K, Yassen T, Cherif M, D'onghia AM, Ippolito A (2013) Applications of salts and natural substances to reduce incidence of Penicillium rot on Maltaise and Valencia late oranges in Tunisia. Arab J. Plant Prot. 27:22-31.

Sani I, Abdulhamid A, Bello F (2014) Preliminary phytochemical screening of Eucalyptus camaldulensis leaves, stem-bark, root, fruits and seeds aqueous and ethanolic extracts. J. Sci. Innovative Res. 3: 523-526

Shagal MH, Kubmarawa D, Tadzabia K, Dennis KI (2012) Evaluation of phytochemical and antimicrobial potentials of roots, stem-bark and leaves extracts of Eucalyptus camaldulensis, African J.Pure Applied Chem. 6: 74-77.

Stephan G, Schmitt A, Corvalho SM, Seddon B, Koch E (2005) Evaluation of biocontrol preparations and plant extracts for the control of Phytophthora infestans on potato leaves. Eur. J. Plant Pathol. 112:235-346.

Stinson EE, Osman SF, Heisler EG, Sicihano J, Bill DD (1981) Mycotoxin production in whole tomatoes, apples oranges and lemons. J. Agr. Food Chem. 29:790-792.

Tabti L, Dib ME, Benyelles NG, Djabou N, Alam SB, Paolini J, Costa J, Muselli A (2015) Fatty-acid composition and antifungal activity of extracts of Thymus capitatus. J. Herbs, Spices and Medic. Plants 21: 203-210

Täckholm V (1974) Student's flora of Egypt. 2nd ed. Cairo Univ. Publ., Cooperative Printing Company, Beirut. 
Ukeh JA, Chiejina N V (2012) Preliminary investigations of the cause of post-harvest fungal rot of tomato. IOSR J Pharm. Biol. Sc. 4: 36-39.

Wills RH, Lee TH, Graham D, Mcglassom WB, Hall EG (1981) Postharvest: An introduction to the physiology and handling of fruits and vegetables. Granada Publishing Ltd., London, pp 432.

Wilson CL, Wisniewski ME, Biles CL, McLaughlin R, Chalutz E, Droby S (1991) Biological control of post-harvest diseases of fruits and vegetables: alternative to synthetic fungicides. Crop Prot. 10: 172-177.
Yaber Grass, M. A.; Leicach S. R. (2011). Changes in Senecio grisebachii pyrrolizidine alkaloids abundances and profiles as response to soil quality. J. Plant Interactions, Available from http://www.tandfonline.com/doi/abs/10.1080/1742 9145.2011.591504

Zhang HY, Zheng XD, Xi YF (2005) Biological control of post-harvest blue mold of oranges by Cryptococcus laurentii (Kufferath) Skinner. Biol. Control. 50: 331-342.

\title{
عنوان البحث: النشاط الضد فطري لمستخلصات بعض النباتات الطبية ضد الفطريات الممرضة السائدة التي تسبب فساد بعض الفوان الفوانه \\ زكريا عوض محمد بقا'وممدوح سالم سراج' وأميرة إبراهيم فرج ' ' ق مسم النبات - كلية العلوم - جامعة دمياط
}

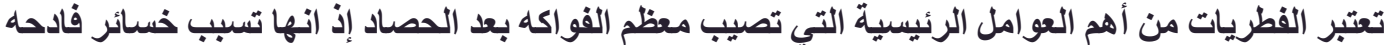

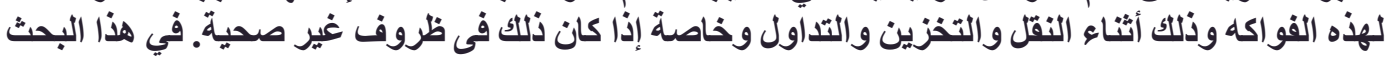

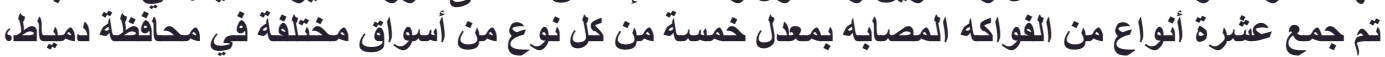

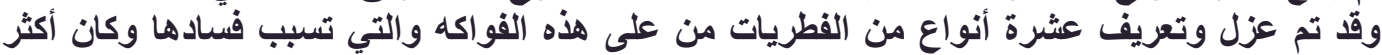

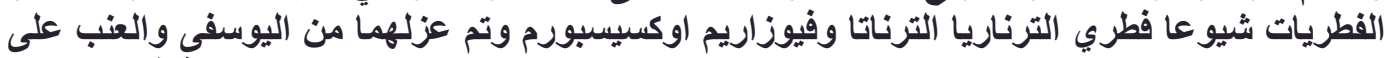

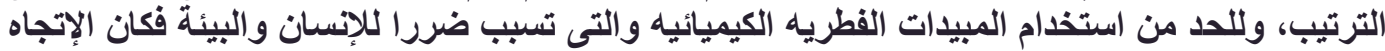

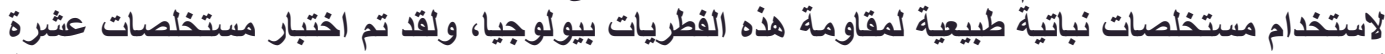

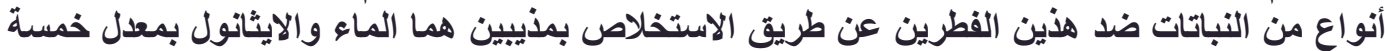

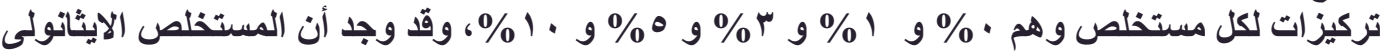

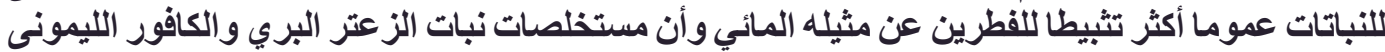

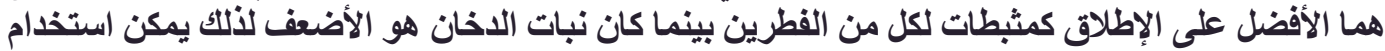

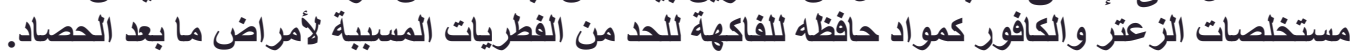

